\title{
レーザー蛍光誘起法を用いた植生開水路流れに おける乱流拡散特性に関する研究
}

\author{
EXPERIMENTAL STUDY ON TURBULENT DIFFUSION IN VEGETATED OPEN- \\ CHANNEL FLOWS BY USING LASER INDUCED FLUORESCENCE METHOD
}

\author{
山上路生 1 ・禰津家久 2 ・岡本隆明 $3 \cdot$ 中村元太 ${ }^{4}$ \\ Michio SANJOU, Iehisa NEZU, Taka-aki OKAMOTO and Genta NAKAMURA \\ 1正会員 博(工) 京都大学助教 工学研究科社会基盤工学専攻（ \\ 2フェロー 工博 京都大学教授 工学研究科社会基盤工学専攻（同上） \\ 3学生会員 修士課程 京都大学 工学研究科社会基盤工学専攻（同上） \\ 3学生会員 京都大学 工学部地球工学科（同上）
}

\begin{abstract}
In actual rivers, many aquatic plants are often observed and submerged canopy flow appears in floods. Submerged plants create complex flow patterns, in which wakes behind vegetation and coherent motions are generated. In particular, mass and momentum transfers and the mixing process are promoted significantly between the in-canopy layer and over-canopy layer. It is, therefore, of great importance for river ecosystem to reveal turbulent diffusion in submerged vegetated open-channel flows. In this study, both of PIV and laser induced fluorescence (LIF) measurements were conducted simultaneously with a pair of high-speed cameras in order to evaluate the relation between the turbulent diffusion property and the coherent motions.
\end{abstract}

Key Words : Turbulence diffusion, vegetated open-channel flow, LIF and PIV

\section{1. はじめに}

水生植生が路床に繁茂する自然河川では，水位上昇時 に低流速部の植生層内域（キャノピー領域）と高速流部 の植生層外域（かぶり水深領域）から構成される複雑な 流れとなる．特に高速流の下降運動であるsweep と低速 流の上昇運動であるejectionが存在することが知られてい る. 河川生態系の維持や水域環境の保全において, キャ ノピー領域とかぶり水深領域における酸素ガス, 熱およ び溶存物質濃度の分布や交換特性を解明することは極め て重要である。これらのスカラー輸送はejectionやsweep と大きな関係があると予想されるため，本論文では植生 開水路流れにおける染料濃度の乱流輸送メカニズムを対 象に研究を進める.

このようなキャノピー流れの乱流特性の解明は主に気 象学の分野で進展した. Raupachグループは粗面空気流 における乱流統計量の分布や乱れエネルギーの生成特性 を風洞実験によって明らかにした ${ }^{1), 2)}$ 。さらにGaoら $ら^{3)}$ は 森林キャノピーの空気流において流速と気温の同時計測 を行い，高速下降流sweep と低速上昇流のejectionによっ
て熱輸送が支配されることを明らかにした，一方，水理 学分野でも植生開水路流れの抵抗特性や乱流構造につい ては多くの既往研究があるが, 最近では物質輸送や拡散 特性への関心も高い. 例えばNepf ${ }^{4)}$ は植生開水路流れに おける染料濃度の拡散と乱流輸送の関係特性を報告して いる.さらにNepf ら ${ }^{5}$ はランダムウォークモデルに基づ く濃度拡散モデルを提案するとともに, 水深が植生高さ よりも小さい非水没植生開水路に適用し，植生背後の wakeによる水平方向の乱流拡散について考察した.

しかしながら上述のNepfグループは速度と濃度の同時 計測は行っておらず，これらの相関特性や植生開水路に おける乱流拡散メカニズムについては未解明点が多い.

著者らのグループは数年前より植生開水路流れのLDA 計測 ${ }^{6}$, PIV 計測 ${ }^{7}$ および 3 次元のLES ${ }^{7)}$ に取り組んでおり, キャノピー領域とかぶり領域の間にはスイープやエジェ クションによる運動量交換が促進されることを水理実験 と数值計算の双方から明らかにしたが，物質輸送におよ ぼす組織乱流構造の役割については検討していない. そ こで本研究ではレーザー蛍光誘起法(LIF) とPIVを併用し て, 染料濃度と流速の多点同時計測を行い, 植生開水路 流れにおける乱流輸送特性を明らかにする. 


\section{2. 流速と染料濃度の同時計測法}

本研究で扱う植生開水路流れにおける乱流拡散現象の イメージを図-1に示す．植生が完全に水没する植生流れ (submerged flow)では，キャノピー内部と外部で流速差が 顕著となり，エジェクションやスイープなどの組織乱流 構造が発生する．これらはキャノピー内部と外部の物質 交換に大きな影響を与えると思われる. 実河川では河床 における土砂や栄養塩濃度が大きく, これらの拡散挙動 は水生生態系の生育活動と重要な関係がある.この点を 詳細に解明するためには乱流拡散特性を知る必要がある. したがって本研究では水路底面付近に染料を流入させて, この濃度分布と流速分布の時系列変化を同時計測した.

水理実験は全長 $10 \mathrm{~m}$, 幅 $40 \mathrm{~cm}$, 高さ $50 \mathrm{~cm}$ の総ガラス 製の可変勾配型水路で行った．座標系および植生模型の 詳細は著者らの前報() と同一である. 図-2は計測システ ムと座標系を示したものである. $x, y$ および $z$ はそれぞ れ, 流下方向, 鉛直方向および横断方向である. $U, V$ および $W$ は各方向における時間平均流速， $u, v$ および $w$ はそれぞれ瞬間流速の時間平均流速からの偏差すな わち乱れ成分を示寸. 同様に染料の時間平均濃度を $C$, その偏差を $c$ とする. $H$ は水深, $h$ は植生高さである.

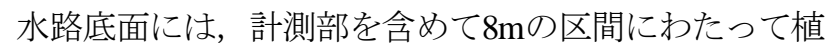
生模型を配置した，植生模型は高さ $5 \mathrm{~mm}$ ，厚さ $1 \mathrm{~mm}$ よび幅 $8 \mathrm{~mm}$ のアクリル板と $8 \mathrm{~mm}$ 辺の立方体土台から構 成される. 図中の $L_{v}$ および $B_{v}$ はそれぞれ主流方向およ び横断方向のモデル植生の配置間隔であり, 既往研究1) 2), 5)の植生配置密度を参考に $L_{v}=B_{v}=24 \mathrm{~mm}$ とした. また 実際の水生植生は流れに応じて変形するが，本研究は植 生流れの乱流拡散研究の第一ステージであり, 固定の植 生模型を用いた. 主流方向の原点 $x=0$ はノズル先端, 鉛直方向の原点 $y=0$ は水路底面にとった.ノズルは外 径1 $1 \mathrm{~mm}$ のステンレス製で注射針先端を底面にセットした. 横断位置は後述するレーザーライトシート光位置に一致 させた. 濃度0.1g/のローダミンBを染料としてノズルか ら水中に注入した. この際, 注入速度はあらかじめPIV によって計測した同一高さ位置における時間平均主流速 と同じになるように調整した.

水路の両側方には 2 台の高速度CMOSカメラ $(1000 \times$

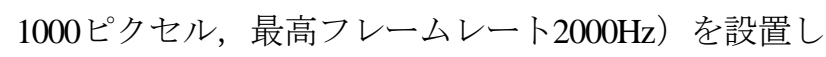
て流れ場を可視化計測した． 1台のカメラはPIVの計測 用で，残りの 1 台はLIF用である. 2 台のカメラはパル スジェネレータからのトリガー信号により同時制御が可 能である.PIVのトレーサーには粒径 $100 \mu \mathrm{m}$ のポリスチ

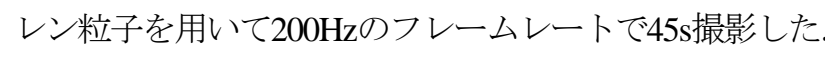
撮影画像の輝度值から濃度相関法によって $(\tilde{u}, \tilde{v})$ の瞬間

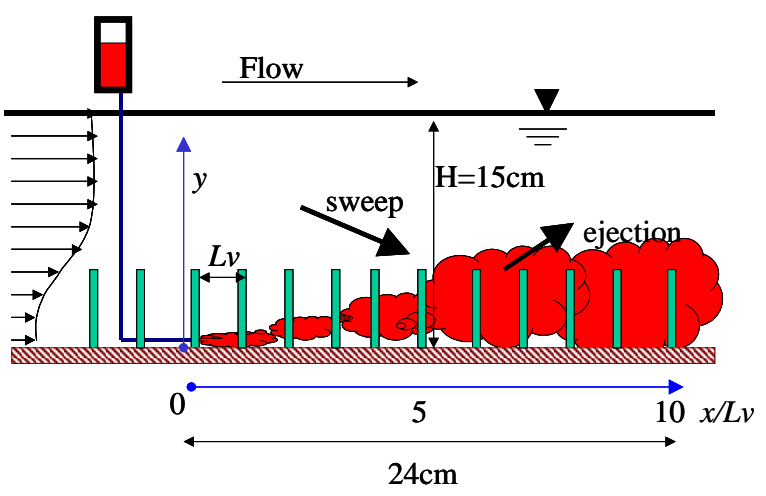

図-1 植生開水路流孔における乱流拡散のイメージ

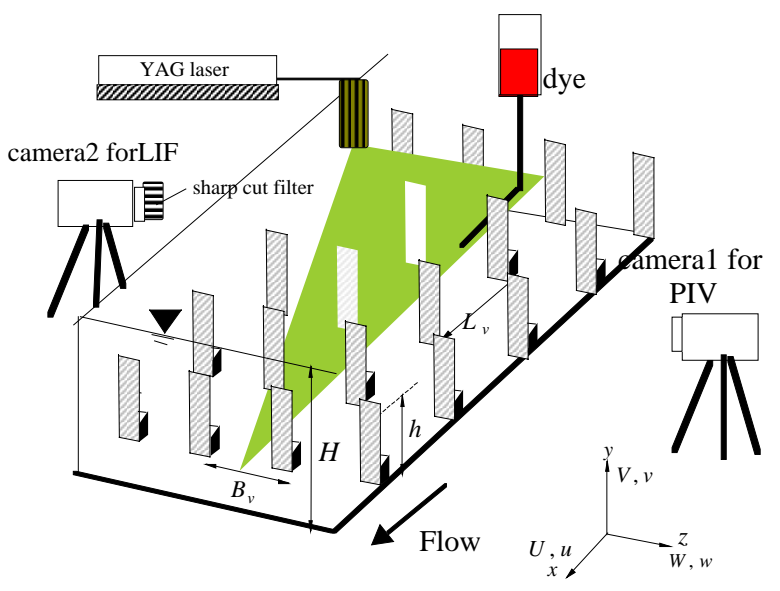

図-2ＰIV\&LIF同時計測の計測システム

速度成分を算出した。光源には $2 \mathrm{~W}$ の連続YAGレー ザーを用いて水路上方から厚さ $2 \mathrm{~mm}$ のレーザーライト シート光(LLS)を主流方向に平行に照射した. 横断方向 の照射位置は水路センターライン近傍に位置する隣あう $2 つ$ 植生模型列の真中とした. この $x-y$ 面を 2 台の カメラで同時撮影した。 一つの撮影領域サイズは $15 \mathrm{~cm}$ $\times 15 \mathrm{~cm}$ である. 流下方向に $x=0 \sim 15 \mathrm{~cm}$ と $x=15$ 〜 $30 \mathrm{~cm}$ の つの撮影領域を設定し，それぞれの領域につ いてPIVとLIF計測を行った．YAGレーザー光を照射さ れたPIVトレーサーの反射光は波長が537nmである。一 方, 誘起蛍光化されたローダミン染料の反射光は $580 \mathrm{~nm}^{9)}$ であるのでLIF用のカメラにはシャープカット フィルタを装着してレーザー誘起蛍光化されたローダミ ン濃度のみが撮影されるように工夫した. 濃度分布は画 像の輝度分布から線形対応させた. 染料は 3 次元的に横 断方向にも拡散するが，LLSによる散乱光のみがCMOS 素子に記録されるのでLLSの 2 次元平面における濃度が 正確に計測できる.

本研究は図-1に示寸水没植生ケース(submerged)の乱流 拡散現象を対象とするが, 比較のために非水没ケース （emergent）も計測した. submergedケースの相対水深は $H / h=3.0$, emergentケースでは $H / h=0.9$ とした. 断 面平均流速 $U_{m}$ は submerged ケースの植生層内領域 $(y / h<1.0)$ での值と emergentケースの值が一致するよう 
(a)

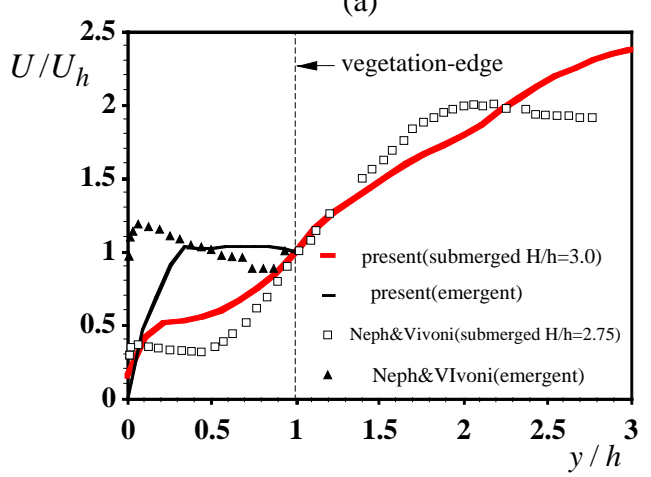

(b)

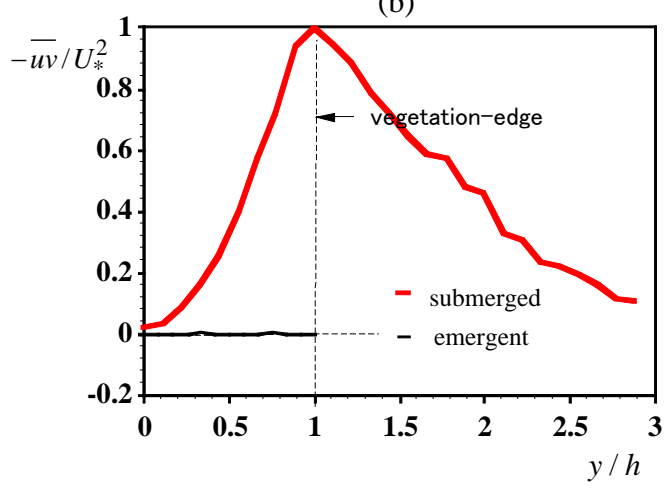

図-3 開水路植生流れの基本構造

(a : 時間平均流速分布， $\mathrm{b}$ : レイノルズ応力分布)

に決定した。その結果， submergedは $U m=10 \mathrm{~cm} / \mathrm{s}$ ， emergentは $U m=4.2 \mathrm{~cm} / \mathrm{s}$ とした. submergedではレイノル ズ数 $\operatorname{Re} \equiv U_{m} H / v$ が 15000 の乱流状態で染料やトレー サーを用いた目視によっても植生先端で横断軸をもつ渦 運動やejectionおよびsweepの組織運動が確認できた.

\section{3. 実験結果と考察}

\section{（1）植生流れの基本構造}

submergedケースとemergentケースの流れの基本特性を 比較するために図-3 (a)および(b) に時間平均流速とレイ ノルズ応力の分布をそれぞれ示す. Neph\&Vivoni ${ }^{10)}$ の結 果もプロットした。彼女らは高さ20mm，6.4mm径の円 筒土台に枝として $0.25 \mathrm{~mm}$ 厚のビニールを 6 つ取り付け た変形植生モデルを底面にランダム配置した．流速分布 はsubmergedについては, 植生先端の值 $U_{h}$, emergentに ついては自由水面に最近傍の計測值を $U_{h}$ とした。レイ ノルズ応力は, submergedでは 植生先端の- $\overline{u v} / U_{*}^{2}$ が 1 となるように定義した摩擦速度 $U_{*}=2.25 \mathrm{~cm} / \mathrm{s}$ で無次元 化した. emergentについてもこの摩擦速度を用いて無次 元表示した.

submergedの流速分布については, 植生層内 $(y / h<1)$ で大きく減速されるため, 植生層外 $(y / h>1)$ との流速 差が顕著となり混合層に類似した分布が夕られる. 後述

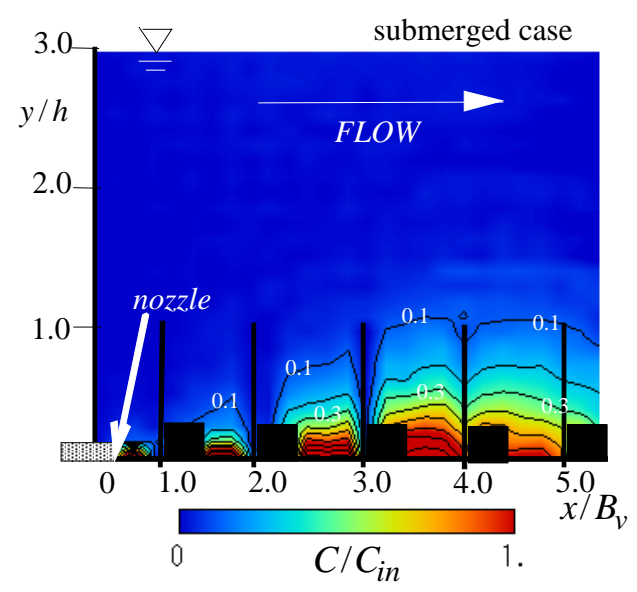

図-4 時間平均濃度のコンター図

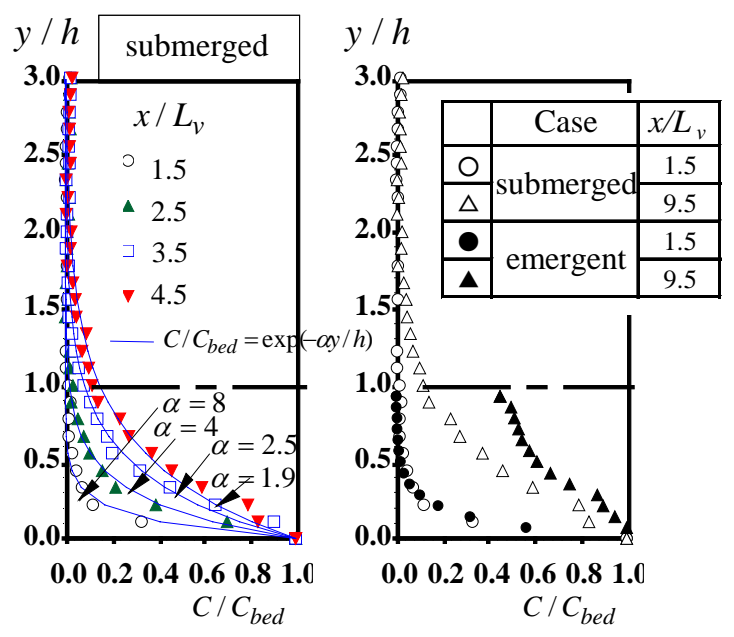

図-5 時間平均した相対濃度の鉛直方向分布

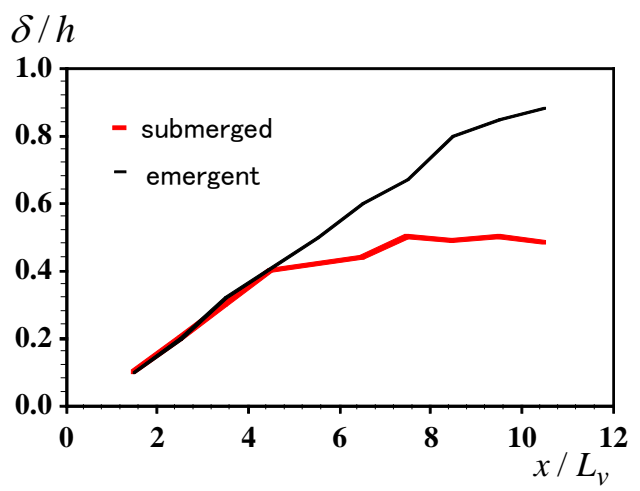

図-6 濃度分布の半值幅の流下方向変化

するように植生先端を中心にせん断領域が形成されると ともにsweepやejectionなどの周期性をもつ組織乱流構造 が引き起こされる。流速勾配 $\partial U / \partial y$ に関する Neph\&Vivoniのケースとのずれは植生密度や植生変形の 有無などが原因と考えられる。またNepf\&Vivoniは $y / h=2$ でvelocity-dipが夕られるが，これは流れのアス ペクト比が小さく2 次流が発生するためと思われる. emergentの場合では底面近くを除いて流速はほぼ一様の 分布をもちNepf\&Vivoniの結果と同様の傾向がみられる. 本実験では植生モデルの土台にレゴブロックを用いたた めに，底面付近でNepf\&Vivoni との差異が生じたものと 


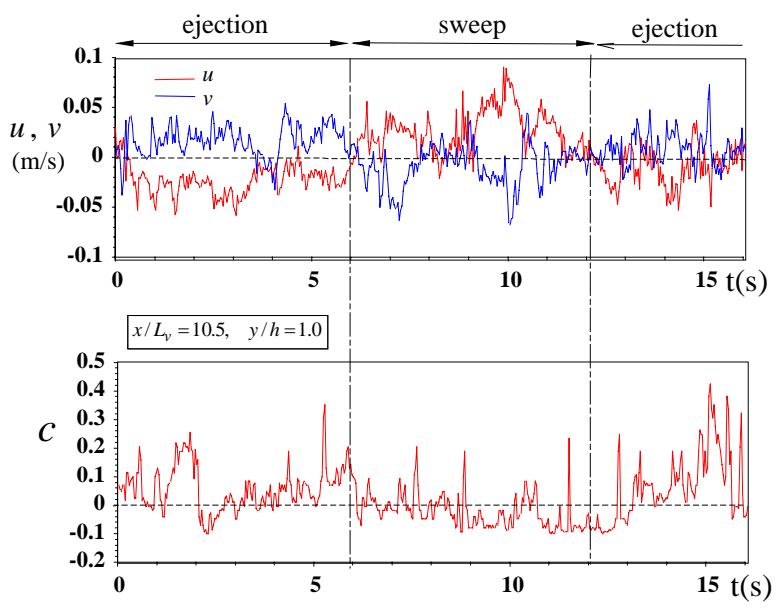

図-7 流速変動と相対濃度変動の時系列データ

思われる.

レイノルズ応力についてはsubmergedの場合, 植生先 端でピーク值が現れる.これは(a) 図で示した流速シア による運動量交換が植生先端を中心に促進されることを 意味しており, 植生乱流の重要な共通知見の一つである. emergent と比較して植生層内においても大きな $-\overline{u v}$ 值が 分布し，植生層外から層内一の運動量輸送が促進される ことがわかる。またemergentにおいては底面近傍で $\partial U / \partial y$ が大きいにも関わらずレイノルズ応力がほぼゼ ロになるが，この付近は低レイノルズ数領域であるため に乱れが発達しないことが考えられる.

\section{（2）時間平均濃度分布}

図-4は時間平均した濃度分布 $C(x, y)$ 分布のコンター である. 結果はノズル出口における時間平均濃度 $C_{i n}$ で 無次元化した相対濃度である. 以下， $C$ は相対濃度を 示寸ものとする. 時間平均濃度分布は鉛直方向に拡がり ながら流下寸る様子がわかる，また底面から水面にかけ て単調減少する.

そこでこれらの分布が指数関数で近似できるかを調べ る. 図-5左図は $x / L_{v}=0.5 \sim 3.5$ における時間平均濃度の

鉛直分布である. 底面近傍の第一計測点 $y_{b} / h=0.06$ の 值 $C_{b e d}$ で無次元化した. いずれの地点の分布も， $\alpha$ を 定数とした次の指数関数で近似できることがわかる.

$$
C / C_{b e d}=\exp \left(-\alpha\left(y-y_{b}\right) / h\right)
$$

図-5右図は両ケースを比較したものである， $x / h=9.5$ ではsubmergedよりも年ergentケースの方が相対濃度分布 は大きいことがわかる.

(1)の近似曲線から求めた濃度分布 $C(y)$ 半值幅 $\delta$ の流 下方向変化を図-6に示寸。 emergent ケースの方が submergedケースよりも $\delta$ の空間的な発達が大きく, 植 生先端付近にまで高濃度分布が輸送される. submerged ケースはemergentケースよりも緩やかに $\delta$ が発達し $x / L_{v}>7$ ではほぼ一定となる，底面から植生先端まで 輸送された染料濃度の一部はejectionによってさらに上方 の植生外層や自由水面領域まで輸送されるが， sweepの 影響によって再び底面付近まで戻される輸送パターンも 存在する．以下ではこの点を中心にejection と sweepが濃 度輸送に与える影響を定量的に考察する。

\section{（3）流速と濃度の時系列特性}

図-7はsubmergedケースの $x / L=10.5, y / h=1.0$ にお ける流速変動成分 $u, v$ および相対濃度の変動成分 $c$ の 時系列データを示す. ejectionは低速流の上昇運動 $(u<0, v>0)$, sweep 高速流の下降運動 $(u>0, v<0)$, である.これらの符号パターンとベクトル動画から判定 したejectionとsweepのタイミングを図中に示した．特に ejection時には $c>0$, sweep時には $c<0$ となるタイミン グが観察されるが，このことからもejectionによって底面 からの高濃度流体が上方へ輸送され，瞬間的に濃度が上 昇寸ることが確認できる．またsweepが植生外層の低濃 度の流体を植生層内に輸送するとともに, ejectionによる 濃度の上方輸送を抑制する働きをもつこともわかる。こ のことが適用できないタイミングも存在するが，これら の時刻ではsweepやejectionよりも 2 次流による横断方向 の濃度輸送が支配的になると予想される.
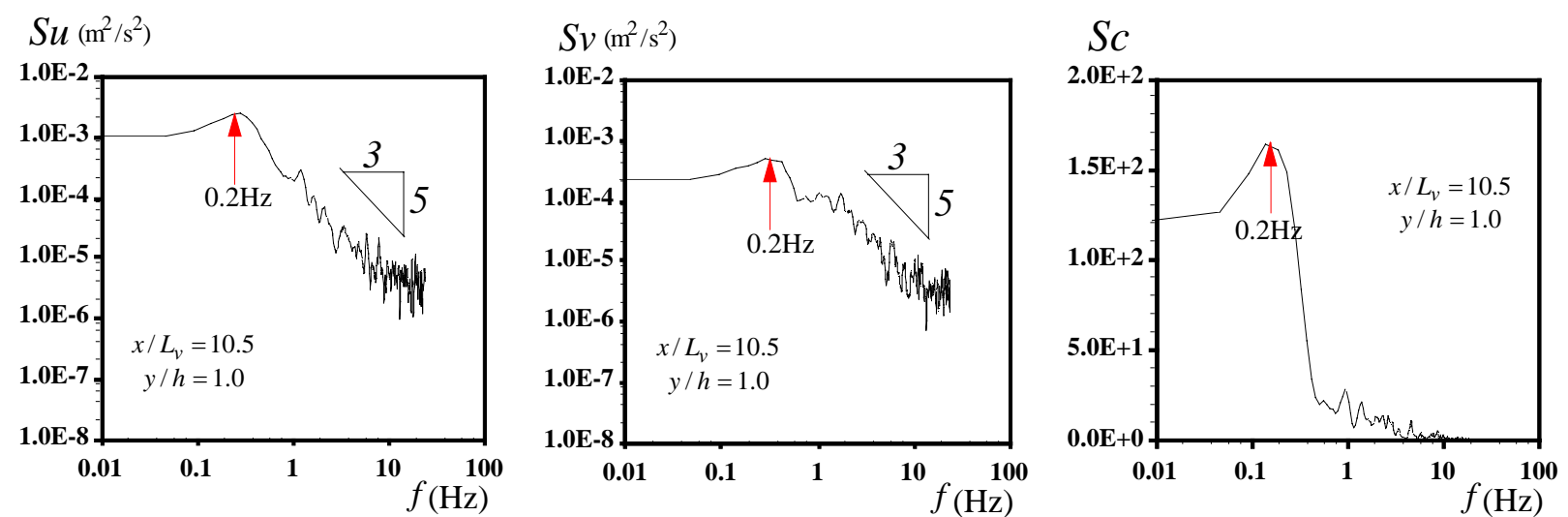

図-8 植生先端におけるスペクトルの比較（左 : 主流速，中 : 鉛直流速，右 : 相対濃度） 
(a) sweep

$t=0$ (s)
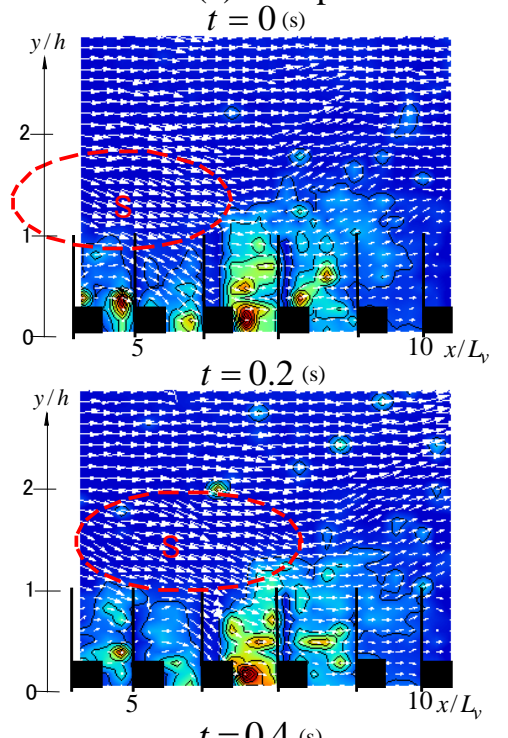

$t=0.4(\mathrm{~s})$

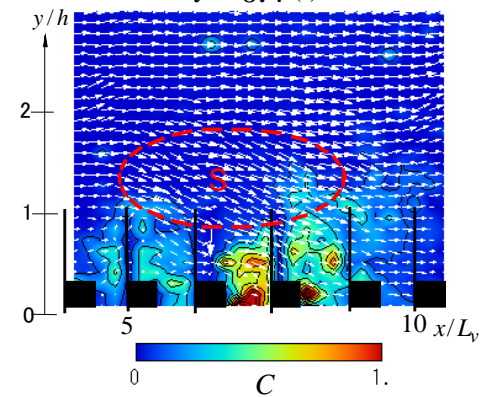

図-9＼cjkstart瞬間速度ベクトルと濃度コンターの一例 (b) ejection
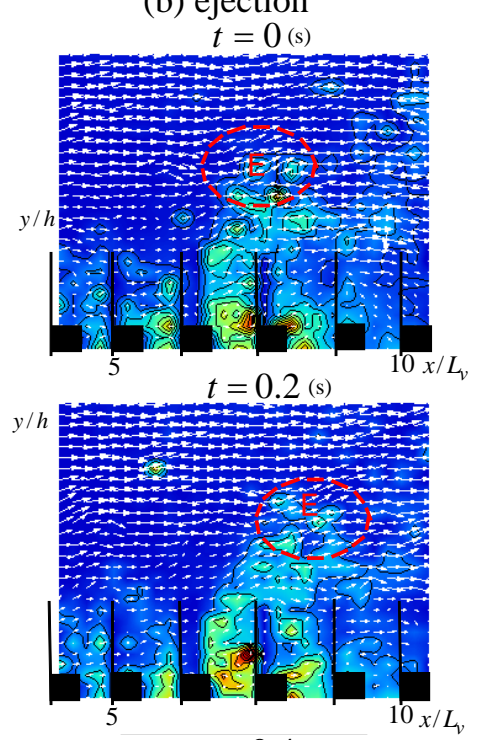

$t=0.4$ (s)

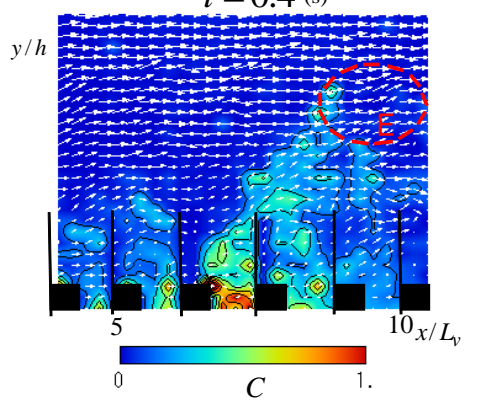

例（左 : sweep発生時，右 : ejection発生時）
図-8 は submerged ケースの $x / L_{v}=10.5$ および $y / h=1.0$ における主流速，鉛直流速および相対濃度の パワースペクトル $S_{u} ， S_{v}$ および $S_{c}$ を示す. $S_{c}$ につい てはピークを強調するために普通座標で表示した，低周 波領域で $S_{u}$ および $S_{v}$ ともにスペクトルピークがみられ る. 両者ともに同一のピーク周波数 $f_{p}=0.2 \mathrm{~Hz}$ をち, 図-7で示したようなsweepおよびejectionが周期運動であ ることを示している．また $3 \sim 10 \mathrm{~Hz}$ 付近で-5/3乗則が成 立する，濃度変動についても流速変動ほど明確ではない が流速変動と同じピーク周波数をもち，濃度変動と流速 変動は大きな相関性があるといえる.

図一9は瞬間ベクトルと瞬間濃度コンターを例示したも のである. (a)はsweepおよび(b)はejectionが現れる瞬間画 像の例である. (a)図のsweepについては $x / L_{v}=5$ で植生 層外から層内一下降する高速流体が観察される. 時刻と ともにsweep自体が流下輸送される. sweepの移流ととも に $x / L_{v}=6 \sim 7$ 間のキャノピー領域では $y / h=1$ の先端 付近で濃度分布が時間減少寸ることがわかる。 一方，(b) 図は $t=0 \mathrm{~s}$ では $y / h=1.5$ 付近に局所的に高濃度分布が 存在する. sweepと同様にejectionも時間経過により流下 方向に輸送される，それにともない0.4秒後には高濃度 分布は $y / h=2.0$ 付近に観察される.
流速変動と濃度変動の相関值である $\overline{v c}$ および $\overline{u c}$ は乱 流拡散を定量評価するための重要な值であるが，流速と 物質濃度の複数点同時計測が必要なために，勾配拡散モ デルが導入される場合が多い. 本研究ではPIVとLIFの同 時計測により直接的に算出できる．ここでは鉛直流速変 動と濃度変動の相関である $\overline{v c}$ に注目し，さらにejection と sweepの寄与を比較するために条件付サンプリングを 行う. ejection $(u<0, v>0)$ 時のみのデータから計算した ものを $\overline{v c}_{e}, \quad$ sweep $(u>0, v<0)$ 時のものを $\overline{v c}_{s}$ とする. 図-10は $x / L_{v}=8.5$ における $\overline{v c}, \overline{v c}_{e}$ および $\overline{v c}_{s}$ の鉛直方 向分布である. $y / h=1$ 付近で流体と流速の高い相関が みられる. $\overline{v c}_{s}$ と $\overline{v c}_{e}$ を比較すると, 底面から植生先端 付近までは $\overline{v c}_{s}>\overline{v c}_{e}$ でsweepによる寄与がejectionによる ものを大きく上回るが， $y / h>1.45$ では $\overline{v c}_{e}>\overline{v c}_{s}$ とな る.したがって植生先端からキャノピー内部においては ejectionによって巻き上げられた濃度がsweepによって再 度底面側に輸送されると考えられる. 図-11はレイノル ズ応力 $-\overline{u v}$ に関する したものである. それぞれ $R S_{2}$ および $R S_{4}$ とする. 植 生層内から植生層外の $y / h=1.35$ ではsweepの寄与が大 きく, 植生層外の高速流体が活発に植生層内一輸送され る。これは空気キャノピー流 でも指摘されている組織 


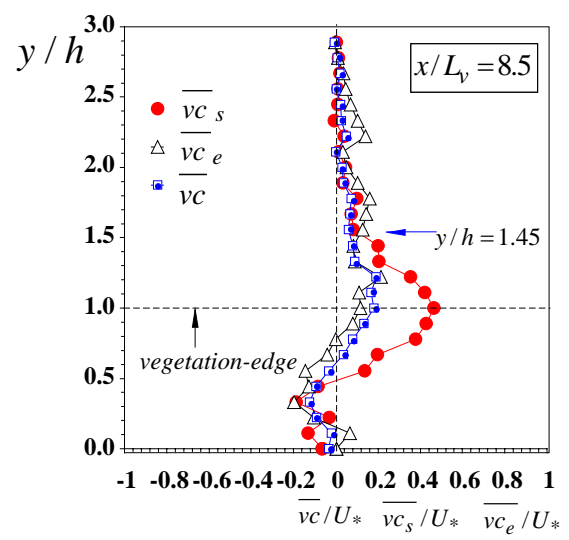

図-10 鉛直流速と相対濃度の相関分布

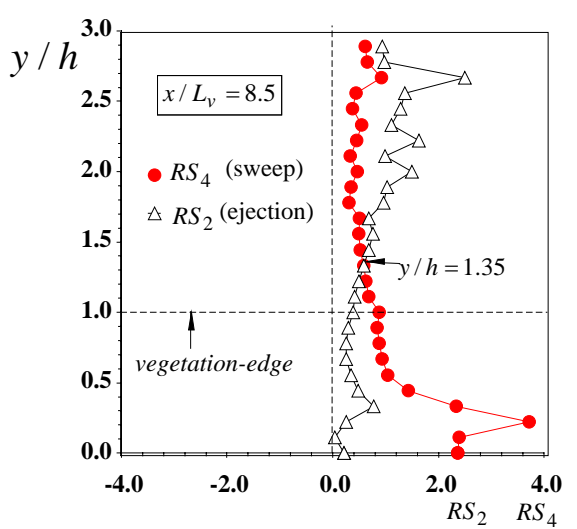

図-11 レイノルズ応力へのsweep およびejectionの寄与率比較

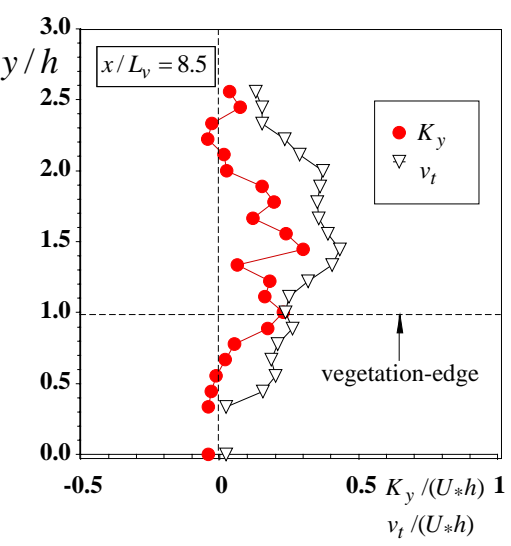

図-12 乱流拡散係数と渦動 粘性係数の分布
乱流構造の重要な特性である.ここで図-10と図-11を比 較すると少しずれがあるものの濃度変動へのejection と sweepの逆転高さ $(y / h=1.35)$ はレイノルズ応力の寄与 率の逆転高さ $(y / h=1.45)$ とほぼ一致する。 このことか らも組織乱流は濃度輸送に大きな影響をもつといえる。

\section{（4）乱流拡散係数の評価}

レイノルズ応力や流速と濃度の相関值は勾配拡散モデ ルによって次のように表せる.

$$
-\overline{u v}=v_{t} \partial U / \partial y \quad \text { および }-\overline{v c}=K_{y} \partial C / \partial y
$$

ここで $v_{t}$ は渦動粘性係数， $K_{y}$ は鉛直方向の乱流拡散係 数である. 図-12は式(2)より求めた $v_{t}$ と $K_{y}$ の鉛直分布 を比較したものである. $K_{y}$ はデー夕にばらつきが認め られるもののキャノピー内部 $(y / h<1)$ から植生先端 $(y / h=1)$ にかけて増加し, 水面領域 $(y / h>2)$ で減少 する. $1<y / h<2$ ではピーク值をもち放物線型に近い 分布をもち, $v_{t}$ の分布と類似寸る. $1<y / h<2$ では乱 流シュミット数 $S_{c} \equiv v_{t} / K_{y}$ が1 2のオーダーとなり, 植生先端付近では実用上， $K_{y}=v_{t}$ としてもよいかもし れない，今後はより多くの水理条件下で検討して， $S_{c}$ の特性や横断方向への拡散効果についても考察したい.

\section{4. おわりに}

本研究では植生開水路流れにおける濃度拡散と組織乱 流構造の関係特性を実験的に明らかにしたものである. 以下に得られた結果をまとめて示寸.

1）PIVとLIFを組み合わせた実験システムによって流速 と染料濃度の時間空間分布を同時に計測した。

2) submergedケースの植生流れはemergentケースに比心 て，上方に拡散された物質濃度がsweepによって再 度下方に輸送される。

3）流速変動と濃度変動のピークスペクトルはほぼ一致 し，濃度変動はsweepやejection 之同周期の低周波変
動を有する.

4) キャノピー領域における濃度変動への組織構造の寄 与はsweepの方がejectionよりも大きい.

5）乱流拡散係数は植生先端付近を中心に渦動粘性係数 と同オーダーの值をもつ.

\section{参考文献}

1) Raupach, M. R. and Thom, A.S. : Turbulence in and above Plant Canopies, Ann. Rev. Fluid Mech., Vol.13, pp.97-129, 1981.

2) Raupach, M. R., Finnigan, J.J. and Brunet, Y. : Coherent Eddies and Turbulence in Vegetation Canopies: The Mixing-layer Analogy., Boundary Layer Meteorology, Vol.78, pp.351-382, 1996.

3) Gao, W., Shaw, R.H. and Pawu, K.T. : Observation of Organized Structure in Turbulent Flow within and above a Forest canopy urbulence in and above Plant Canopies, Boundary Layer Meteorology, Vol.47, pp.349-377, 1989.

4) Nepf, H. M.: Drag, Turbulence, and Diffusion in Flow through Emergent Vegetation, Water Resources Research, Vol.35, pp.479489, 1999.

5) Nepf, H. M., Sullivan, J. A. and Zavistoski, R. A.: A Model for Diffusion within Emergent Vegetation, Linnol. Oceanogr. Vol.42(8), pp.1735-1745, 1997.

6) 䙥津家久・山上路生・岡本隆明 : 植生キャノピー開水 路流れの乱流構造とディスパーシブ効果に関する実験 的研究，水工学論文集，Vol.50, pp.1135-1140, 2006.

7) Nezu, I., Sanjou, M. and Okamoto, T. : PIV Measurements in Vegetated Open-channel Flows, Proc. of 32th IAHR Conference, Venice, paper466, 2007.

8) 山上路生・岡本隆明・禰津家久 : 開水路植生流孔にお ける組織渦のLES解析, 水工学論文集, Vol.51, p.637642, 2007.

9) PIVハンドブック，可視化情報学会編， 2002.

10)Nepf, M. and Vivoni, E. R. : Flow Structure in Depth-limited, Vegetated flow, Vol.105, pp.28547-28557, 2000.

(2007. 9. 30受付) 